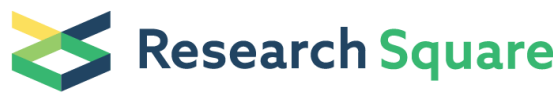 \\ Preprints are preliminary reports that have not undergone peer review. \\ They should not be considered conclusive, used to inform clinical practice, or referenced by the media as validated information.
}

\section{Potential transmission risk of SARS-CoV-2 through medical wastewater in COVID-19 outbreak cities}

Jun-Bo Zhou

Wuhan Center for Disease Control \& Prevention, Wuhan, Hubei 430024, China

Wen-Hua Kong

Wuhan Center for Disease Control \& Prevention, Wuhan, Hubei 430024, China

\section{Sheng Wang}

Wuhan Center for Disease Control \& Prevention, Wuhan, Hubei 430024, China

Yi-Bing Long

Wuhan Center for Disease Control \& Prevention, Wuhan, Hubei 430024, China

Lian-Hua Dong

National Institute of Metrology, Beijing100013, China

Zhen-Yu He

Wuhan Center for Disease Control \& Prevention, Wuhan, Hubei 430024, China

Man-Qing Liu ( $\square$ liumq33@hotmail.com )

Wuhan Center for Disease Control \& Prevention, Wuhan, Hubei 430024, China

\section{Short Report}

Keywords: SARS-CoV-2, droplet digital PCR (ddPCR), COVID-19 outbreak, Wastewater

Posted Date: June 22nd, 2020

DOI: https://doi.org/10.21203/rs.3.rs-3743/v1

License: (c) (i) This work is licensed under a Creative Commons Attribution 4.0 International License. Read Full License

Version of Record: A version of this preprint was published at Virologica Sinica on June 22nd, 2020. See the published version at https://doi.org/10.1007/s12250-021-00373-z. 


\section{Abstract}

COVID-19 outbreak first reported in Wuhan has been officially declared as a global pandemic. Considering the fecal shedding of SARS-CoV-2 has been proven by the viral strains isolated from COVID-19 patient's stool specimens, it proposed the possibility that contaminated wastewater and fomites might involve in the disease transmission in outbreak cities. In this study, we collected the wastewater samples collected from COVID-19 designated hospitals, Fangcang shelter hospitals, quarantine spots and wastewater treatment plants in Wuhan, China, and performed RT-qPCR and droplet digital PCR (ddPCR) for the detection of SARS-CoV-2. Although high concentration of residual chlorine for disinfection of SARS-CoV-2 is persisted, low level SARS-CoV-2 RNA can be detected by qPCR and droplet digital PCR (ddPCR) in the wastewater samples during the COVID-19 outbreak. This preliminary data firstly described in China implies the potential transmission risk of SARS-CoV-2 through medical wastewater in the cities during the COVID-19 outbreak, which calls particular attention for the surveillance and efficient disinfection of wastewater from COVID-19 related facilities.

\section{Introduction}

The outbreak of 2019 novel coronavirus disease (COVID-19) was first reported in Wuhan, China(Kong et al., 2020) and has become the most serious public health emergency in the century (World Health Orgnization)(2020). As the first epicenter of the pandemic, Wuhan experienced a huge medical crisis need created by over 50 thousand confirmed cases, which collapsed the healthcare system of the city. In order to handle the situation and cut the transmission chain, a three-layer COVID-19 healthcare facility system was built (Table 1): 48 hospitals were requisitioned or newly constructed as the designated hospitals for COVID-19 patients in severe or critical conditions; sports stadiums and exhibition centers were renovated into 14 Fangcang shelter hospitals, offering 12,000 beds to treat patients with mild symptoms; and over 100 community quarantine spots were established for the isolation and health monitor of recovered patient, suspected patients and close contacts (Chen et al., 2020). Similar Fangcang shelter hospitals have also been launched in many countries facing explosive COVID-19 related medical needs.

The fecal shedding of SARS-CoV-2 has been proven by the viral strains isolated from COVID-19 patient's stool specimens (Wang et al., 2020). It proposed the possibility that contaminated wastewater and fomites might be involved in the disease transmission (Tang et al., 2020), especially at the healthcare facilities with large number of patients. Several studies have demonstrated the possible transmission of SARS-CoV-2 by wastewater (Kitajima et al., 2020; La Rosa et al., 2020; Orive et al., 2020). Here we report the findings of a small scale experimental investigation, showing that low levels of SARS-CoV-2 RNA was present in the wastewater from COVID-19 related facilities in Wuhan, China.

\section{Materials And Methods}

The study involved four types of facilities, including two designated hospitals, two Fangcang shelter hospitals, two community quarantine spots and two urban wastewater treatment plants (WWTPs) (Table 2). All the six hospitals/quarantine spots were equipped with permanent or temporary onsite liquid waste treatment system (LWTS). Water samples were collected from the water outlet of onsite LWTS at each healthcare facilities, as well as from the water inlet and outlet of WWTPs. Specimens were tested for total residual chlorine immediately using 3,3',5,5'-tetramethylbenzidine colorimetry. The nucleic acid was extracted from $200 \mu$ l of specimen using a GeneRotex automated nucleic acid extraction system (Tianlong, Xi'an, China). A commercial quantitative PCR (qPCR) assay (Daan Gene, Guangzhou, China) was employed to detect the presence of SARS-CoV-2 RNA. Its limit of detection (LoD) for SARS-CoV-2ORF1abandN gene was 500 copies/ml with cut off Ct value of 40 (National Medical Products Administration (NMPA) approval number 20203400063).

In order to detect the potential low level viral RNA pollution, one water sample from each type of facility was chosen to be concentrated (Table 2). For each sample, total of $500 \mathrm{ml}$ homogeneous specimen was collected on 47mm diameter EZ-PAK filter with $0.45 \mu$ mpore (Millipore, US) and retentate was eluted in $2 \mathrm{ml}$ of phosphate buffer saline (pH 9.5) (Zhou et al., 2010). The concentrated samples then underwent nucleic acid extraction and qPCR test as above. In addition, a newly set-up droplet digital PCR (ddPCR) assay targeting ORF1ab, N gene and E gene was exploited. Target 1 (ORF1ab gene) comprised forward 
primer CCCTGTGGGTTTTACACTTAA, reverse primer ACGATTGTGCATCAGCTGA, and the probe 5'-FAM-

CCGTCTGCGGTATGTGGAAAGGTTATGG-BHQ1-3'. Target 2 ( $\mathrm{N}$ gene) comprised forward primer

GGGGAACTTCTCCTGCTAGAAT, reverse primer CAGACATTTTGCTCTCAAGCTG, and the probe 5'- FAM-

TTGCTGCTGCTTGACAGATT-TAMRA-3'. Target 3 (E gene) comprised forward primer ACAGGTACGTTAATAGTTAATAGCGT, reverse primer ATATTGCAGCAGTACGCACACA, and the probe 5'- FAM- ACACTAGCCATCCTTACTGCGCTTCG-BBQ-3'. The tests were performed on a QX200 droplet digital PCR system (Bio-Rad, USA) as previously described (Chan et al., 2020; Corman et al., 2020; Dong et al., 2020). The LoD of ddPCR was 2 copies/reaction for all three targets.

\section{Results}

Ten wastewater samples were collected from eight different sites on March $4^{\text {th }}, 2020$. The samples from healthcare facilities had higher concentrations of residual chlorine $(1 \mathrm{mg} / \mathrm{L}$ to $>10 \mathrm{mg} / \mathrm{L})$ than those from WWTPs $(<0.5 \mathrm{mg} / \mathrm{L})($ Table 2$)$, which was related to the chlorine-containing disinfectant uses at the onsite liquid waste treatment sites. Most samples were negative in the SARS-CoV-2 RNA qPCR test, yet sample \#6 from a quarantine spot presented weak positive result for the N gene. As to the concentrated water samples, SARS-CoV-2 RNA was detected in all the four samples by either qPCR or ddPCR. Samples from hospital and Fangcang shelter hospital presented higher viral RNA level than those from quarantine spot and WWTP. Notably, the qPCR result of concentrated sample \#6 was negative for $\mathrm{N}$ gene, which could be related to the high level of interfering substance in the concentrated wastewater. The ddPCR assay, on the other hand, detected SARS-CoV-2 RNA in the same sample, showing high sensitivity for the complex sample including multifarious wastewater (Singh et al., 2017).

\section{Discussion}

Although this preliminary observation had very limited sample number, it seems that SARS-CoV-2 RNA pollution in wastewater was a pervasive phenomenon in Wuhan by early March, when there were over 20 thousand COVID-19 patients in the city. Viral RNA was not only found in the liquid waste of medical facilities, but also in the urban sewerage network, which was in accordance to the recent report that viral RNA was detected in the wastewater surveillance in the Netherlands, the United States and Sweden (La Rosa et al., 2020; Mallapaty, 2020; Orive et al., 2020). However, trace of SARS-CoV-2 RNA did not indicate the presence of infectious viral particle. In order to eliminate the wastewater pollution caused by centralized COVID-19 healthcare facilities, additional disinfection of drainage system such as continuous disinfectant drip (Supplementary Figure 1), as well as the standard onsite wastewater disinfection, has been conducted in Wuhan. The viral RNA level detected in our study was very low (under or close to the LoD of qPCR assay), which made wastewater unlikely to be a spread source in this scenario.

To our best knowledge, this is the first study to report the detection of SARS-CoV-2 by ddPCR in China. The detection of SARSCoV-2 RNA from wastewater not only provides warning sign for virus's arrival in a community, but also implies possible transmission of SARS-CoV-2, especially in the outbreak city with centralized isolation hospitals. Considering COVID-19 pandemic has caused lack of testing resources in many countries and regions, we call for particular attention for the surveillance and efficient disinfection of wastewater from COVID-19 related facilities, as well as the systematic study on the role of polluted wastewater in SARS-CoV-2 transmission.

\section{Declarations}

\section{Funding}

This work was supported by The Emergency Scientific Research Project for COVID-19 from Wuhan City to M.-Q. Liu.

\section{Declaration of competing interest}

The authors declare that they have no conflict of interest. 


\section{References}

1. STEPS Sample Size Calculator and Sampling Spreadsheet

(https://www.who.int/ncds/surveillance/steps/resources/sampling/en/). World Health Organization, 2020.

2. Chan JF, Yip CC, To KK, Tang TH, Wong SC, Leung KH, et al. Improved Molecular Diagnosis of COVID-19 by the Novel, Highly Sensitive and Specific COVID-19-RdRp/Hel Real-Time Reverse Transcription-PCR Assay Validated In Vitro and with Clinical Specimens. J Clin Microbiol 2020; 58.

3. Chen S, Zhang Z, Yang J, Wang J, Zhai X, Barnighausen T, et al. Fangcang shelter hospitals: a novel concept for responding to public health emergencies. Lancet 2020; 395: 1305-1314.

4. Corman VM, Landt O, Kaiser M, Molenkamp R, Meijer A, Chu DK, et al. Detection of 2019 novel coronavirus (2019-nCoV) by real-time RT-PCR. Euro Surveill 2020; 25.

5. Dong L, Zhou J, Niu C, Wang Q, Pan Y, Sheng S, et al. Highly accurate and sensitive diagnostic detection of SARS-CoV-2 by digital PCR. MedRxiv 2020: 2020.03.14.20036129.

6. Kitajima M, Ahmed W, Bibby K, Carducci A, Gerba CP, Hamilton KA, et al. SARS-CoV-2 in wastewater: State of the knowledge and research needs. Science of The Total Environment 2020.

7. Kong WH, Li Y, Peng MW, Kong DG, Yang XB, Wang L, et al. SARS-CoV-2 detection in patients with influenza-like illness. Nat Microbiol 2020; 5: 675-678.

8. La Rosa G, laconelli M, Mancini P, Ferraro GB, Veneri C, Bonadonna L, et al. First detection of SARS-CoV-2 in untreated wastewaters in Italy. Science of The Total Environment 2020.

9. Mallapaty S. How sewage could reveal true scale of coronavirus outbreak. Nature 2020; 580: 176-177.

10. Orive G, Lertxundi U, Barcelo D. Early SARS-CoV-2 outbreak detection by sewage-based epidemiology. Science of The Total Environment 2020; 732.

11. Singh G, Sithebe A, Enitan AM, Kumari S, Bux F, Stenstrom TA. Comparison of droplet digital PCR and quantitative PCR for the detection of Salmonella and its application for river sediments. J Water Health 2017; 15: 505-508.

12. Tang A, Tong ZD, Wang HL, Dai YX, Li KF, Liu JN, et al. Detection of Novel Coronavirus by RT-PCR in Stool Specimen from Asymptomatic Child, China. Emerg Infect Dis 2020; 26: 1337-1339.

13. Wang W, Xu Y, Gao R, Lu R, Han K, Wu G, et al. Detection of SARS-CoV-2 in Different Types of Clinical Specimens. JAMA 2020.

14. Zhou XH, Li H, Yang XF, Ke CW, Chen CD, Zheng HY, et al. Concentration and absolute quantitative detection of the norovirus of the water specimens. Journal of Tropical Medicine 2010; 10: 137-40.

\section{Tables}

Table 1.Three-layer COVID-19 healthcare facility system built in Wuhan (data on Feb 29, 2020)

\begin{tabular}{|lllll|}
\hline Facility type & Objective patients & $\begin{array}{l}\text { Facilities } \\
\text { No. in } \\
\text { Wuhan }\end{array}$ & $\begin{array}{l}\text { Beds } \\
\text { provided }\end{array}$ & Healthcare personnel \\
\hline $\begin{array}{l}\text { Designated } \\
\text { hospitals }\end{array}$ & COVID-19 patients in severe or critical conditions & 48 & 26911 & \\
\hline $\begin{array}{l}\text { Fangcang } \\
\text { shelter } \\
\text { hospitals }\end{array}$ & Patients with mild symptoms* & 16 & $\begin{array}{l}\text { (6704 } \\
\text { vacant) }\end{array}$ & \\
$\begin{array}{l}\text { Community } \\
\text { quarantine } \\
\text { spots }\end{array}$ & $\begin{array}{l}\text { Isolation and health monitor of recovered } \\
\text { patients, suspected patients and close contacts }\end{array}$ & $>100$ & $\begin{array}{l}\text { (7255 } \\
\text { vacant) }\end{array}$ & $\begin{array}{l}11172 \\
\text { nurses per } 50 \text { patients }\end{array}$ \\
\hline
\end{tabular}


*The Fangcang shelter hospital will only admit patients aged between 18 and 65 with the ability to care for themselves and without other respiratory diseases, cardiovascular and cerebrovascular diseases or mental diseases. The patients admitted should also be tested negative for the flu virus at the same time.

Table 2. Presence of SARS-CoV-2 RNA in the wastewater from different locations in Wuhan, China, March $4^{\text {th }}, 2020$ 


\begin{tabular}{|c|c|c|c|c|c|c|c|c|c|c|}
\hline \multirow{3}{*}{\multicolumn{2}{|c|}{$\begin{array}{l}\text { Facility (Patient } \\
\text { capacity) }\end{array}$}} & \multirow{3}{*}{$\begin{array}{l}\text { Sampling } \\
\text { site }\end{array}$} & \multirow{3}{*}{$\begin{array}{l}\text { Concentration } \\
\text { of chlorine } \\
\text { residual } \\
\text { (mg/L) }\end{array}$} & \multirow{2}{*}{\multicolumn{2}{|c|}{$\begin{array}{l}\text { Before concentration } \\
\text { qPCR result } \\
\text { (Ct value) }\end{array}$}} & \multicolumn{5}{|c|}{ After concentration } \\
\hline & & & & & & \multicolumn{2}{|c|}{$\begin{array}{l}\text { qPCR result } \\
\text { (Ct value) }\end{array}$} & \multicolumn{3}{|c|}{$\begin{array}{l}\text { ddPCR result } \\
\text { (copies/reaction) }\end{array}$} \\
\hline & & & & ORF1ab & $\mathrm{N}$ & ORF1ab & $\mathrm{N}$ & ORF1ab & $\mathrm{N}$ & $E$ \\
\hline \multicolumn{11}{|c|}{$\begin{array}{l}\text { Designated } \\
\text { hospital }^{\dagger}\end{array}$} \\
\hline 1 & $\begin{array}{l}\text { Wuchang } \\
\text { Hospital } \\
\text { (504) }\end{array}$ & $\begin{array}{l}\text { Outlet of } \\
\text { the West } \\
\text { Zone } \\
\text { onsite } \\
\text { LWTS }\end{array}$ & $>10$ & Negative & Negative & NT & NT & NT & NT & NT \\
\hline 2 & $\begin{array}{l}\text { The } \\
\text { Central } \\
\text { Hospital } \\
\text { of } \\
\text { Wuhan } \\
(543)\end{array}$ & $\begin{array}{l}\text { Outlet of } \\
\text { the onsite } \\
\text { LWTS }\end{array}$ & 6 & Negative & Negative & 35.90 & 33.63 & 134 & 42 & 10.2 \\
\hline \multicolumn{11}{|c|}{$\begin{array}{l}\text { Fangcang } \\
\text { shelter } \\
\text { hospital }^{\dagger}\end{array}$} \\
\hline 3 & $\begin{array}{l}\text { Jiangxia } \\
\text { Cabin } \\
\text { Hospital } \\
(564)\end{array}$ & $\begin{array}{l}\text { Outlet of } \\
\text { the onsite } \\
\text { LWTS }\end{array}$ & 1 & Negative & Negative & NT & NT & NT & NT & NT \\
\hline 4 & $\begin{array}{l}\text { Jiangan } \\
\text { Cabin } \\
\text { Hospital } \\
(1000)\end{array}$ & $\begin{array}{l}\text { Outlet of } \\
\text { the onsite } \\
\text { LWTS }\end{array}$ & 3 & Negative & Negative & 33.64 & 32.31 & 402 & 26 & 36 \\
\hline \multicolumn{11}{|c|}{$\begin{array}{l}\text { Community } \\
\text { quarantine } \\
\text { spot }^{\dagger}\end{array}$} \\
\hline 5 & $\begin{array}{l}\text { Guanggu } \\
\text { New } \\
\text { Beacon } \\
\text { Hotel } \\
(60)\end{array}$ & $\begin{array}{l}\text { Outlet of } \\
\text { the onsite } \\
\text { LWTS }\end{array}$ & 5 & Negative & Negative & NT & NT & NT & NT & NT \\
\hline 6 & $\begin{array}{l}\text { Jinyinhu } \\
\text { New } \\
\text { Beacon } \\
\text { Hotel } \\
(167)\end{array}$ & $\begin{array}{l}\text { Outlet of } \\
\text { the onsite } \\
\text { LWTS }\end{array}$ & $\begin{array}{l}\text { NT (high } \\
\text { turbidity) }\end{array}$ & Negative & 38.96 & Negative & Negative & 44 & 6.6 & 11 \\
\hline \multicolumn{11}{|c|}{ WWTP } \\
\hline 7 & $\begin{array}{l}\text { Qingshan } \\
\text { WWTP }\end{array}$ & $\begin{array}{l}\text { South } 3 \# \\
\text { wastewater } \\
\text { inlet }\end{array}$ & $<0.5$ & Negative & Negative & NT & NT & NT & NT & NT \\
\hline 8 & $\begin{array}{l}\text { Qingshan } \\
\text { WWTP }\end{array}$ & $\begin{array}{l}\text { South } 3 \# \\
\text { water } \\
\text { outlet }\end{array}$ & $<0.5$ & Negative & Negative & NT & NT & NT & NT & NT \\
\hline 9 & $\begin{array}{l}\text { Hanxi } \\
\text { WWTP }\end{array}$ & $\begin{array}{l}\text { Main } \\
\text { wastewater } \\
\text { inlet }\end{array}$ & $<0.5$ & Negative & Negative & Negative & 36.15 & 110 & 0 & 0 \\
\hline 10 & $\begin{array}{l}\text { Hanxi } \\
\text { WWTP }\end{array}$ & $\begin{array}{l}\text { Main water } \\
\text { outlet }\end{array}$ & $<0.5$ & Negative & Negative & NT & NT & NT & NT & NT \\
\hline
\end{tabular}


Abbreviations: WWTP, wastewater treatment plant; qPCR, quantitative PCR; ddPCR, droplet digital PCR; LWTS, liquid waste treatment system; Ct, cycle of threshold; NT, not tested.

\section{Supplementary Files}

This is a list of supplementary files associated with this preprint. Click to download.

- figS1.png 